\title{
Introduction to Law and Love
}

\author{
Renata Grossi and Joshua Neoh
}

The question of law and love has to be confronted in the soul (as a religious question), in the head (as a political question) and in the heart (as an existential question). This Special Issue of Law in Context tries to make a start in making sense of this multi-faceted question.

As a religious question it is an ancient one, dating at least as far back as Paul. Paul struggled mightily with this question. This question haunted him throughout his entire missionary career. He kept on returning to this question in his letters, again and again. ${ }^{1}$ The urgency of this question was driven largely by the pressing need to define the identity of his early Christian communities in relation to the established Jewish communities. To put the matter crudely, and at the risk of oversimplification, one could say that he defined the former in terms of love and the latter in terms of law. This dichotomy is subject to a great many qualifications, but those are the terms that the Pauline studies have had to contend with. ${ }^{2}$ Having driven a wedge between law and love, Paul still had to articulate a relationship between them. Are Christians bound by the law or are they free from it? Do converts have to be Jews in order to be Christians? Should Christians be circumcised? All these were burning questions of the day, and they were cashed out in terms of law and love. Many centuries later, Martin Luther again made much of these terms in his effort to reform Christianity. ${ }^{3}$

Moving from religion to politics, there is a similar tension being played out. We could ask of a political community what Paul asked of his religious community. There are many ways to phrase this question. We may begin by asking what makes a people. More precisely, we can ask how it is possible to transform persons into a people. On the religious side of the coin, the ancient Israelite answer was the covenant. The covenant created the people of Israel as a people of God. Membership in the covenantal community was achieved through the observance of the law. Paul proposed an alternative: not law, but love. Love would unite the new Christian community. On the political side of the coin, one could give an analogous response. On the one hand, we could say that the constitution creates a people. The constitution founds a political community, invests it with authority, and creates its trans-temporality. On the other hand, like Paul, we could say: not law, but love. That which ultimately sustains the nation and links the person to the

$1 \quad$ See, especially, Paul, Letter to the Romans (Revised Standard Version, 1946) and Paul, Letter to the Galatians (Revised Standard Version, 1946).

2 See, for example, Ed Sanders, Paul, the Law and the Jewish People (SCM Press, 1983).

3 See Martin Luther, Commentary on the Epistle to the Galatians (Theodore Graebner trans, Zondervan Publishing House, 1949). 
nation is a love for the nation. A citizen needs to identify with the nation in the deep and affective way that only love can. This tension between law and love returns and recurs in political theory debates in different guises every now and then. In the 'ethic of right $\mathrm{v}$ ethic of care' debate and the 'liberalism v communitarianism' debate, there is a truly felt and deeply held concern that the language of rights, which is the quintessential language of law, is an alienating form of discourse. The language of rights places us in a combative and antagonistic posture in relation to one another. It builds walls instead of bridges. This dissatisfaction and discontentment with the language of rights then triggers the search for an alternative paradigm, which will provide an alternative mode of relating to one another. The ethic of care presents itself an alternative to the ethic of right, and communitarianism as an alternative to liberalism. ${ }^{4}$ In short, they are asking: 'where is the love?'

Moving from the public to the private, the same tension is at work in the home, the hearth and the heart. Just as the rule of law has become the highest political ideal in matters of the state, love has become the highest existential ideal in matters of the heart. Romantic love has been described by its theorists as a core of modernity, an undeclared religion, an ultimate source of meaning and happiness. ${ }^{5}$ The message that love is what makes life worth living and deepens our sense of being is now a central message expressed in advertising and our cultural outputs. ${ }^{6}$ Furthermore while it has been largely seen as a western construct ${ }^{7}$ the message is now spreading further. ${ }^{8}$

Things would be fine as long as matters of the state and matters of the heart flow like two rivers, and never the twain shall meet. Alas, meet they do, and often. Sometimes the meeting is congenial, while at other times, less so. When matters of the heart clash with matters of state, law is pitted against love. It is an open question as to which will emerge triumphant. Will legal duties trump the calling of the heart, or will the passion of the heart sweep all things aside? If the clash between law and love cannot but end in tragedy, should law tiptoe around love?

In December 2014, in Canberra, a colloquium on law and love met to consider and contribute to some of these conversations. Some of those discussions form the papers in this Special Issue.

$4 \quad$ See Charles Taylor, 'Cross-Purposes: The Liberal-Communitarian Debate' in Nancy Rosenblum (ed), Liberalism and the Moral Life (Harvard University Press, 1989).

$5 \quad$ See, in particular, Simon May, Love a History (Yale University Press, 2011); Ulrich Beck \& Elizabeth Beck-Gernsheim, The Normal Chaos of Love (Polity, 1994); and Eva llouz, Why Love Hurts: A Sociological Explanation (Polity, 2012).

6 Eva Illouz, Consuming the Romantic Utopia (University of California Press, 1997).

7 Irving Singer, The Nature of Love, vol 1-3, (Chicago University Press, 1984-1987).

8 The idea that romantic love is radical, liberating and modern has spread beyond western societies. It finds expression for example in challenges to common (mis) perceptions of arranged marriages in India. See Rochona Majumbar, Marriage and Modernity Family Values in Colonial Bengal (Duke University Press, 2009). 
Perhaps one of the first and most obvious questions to arise is how we categorise the relationship between law and love. It is a common, if not the most common, perception that law and love are opposites, and are often represented in a dichotomous relationship where law is: reason, predictability, rules, regulation, heteronomy, and love is: emotion, unpredictability, contingency, freedom and autonomy. ${ }^{9}$ This question is considered explicitly in the first two papers in the collection.

Joshua Neoh considers the question as it arises in Paul's Letter to the Romans. He argues that, although Paul's conception of love is antinomian, Paul is not. Although Paul comes close to antinomianism, he never crosses the Rubicon into antinomianism. Paul is keenly aware of the needs of this world inasmuch as he looks forward to the world that is to come. In this world, the need for law has to compete with the dream of love - till kingdom come.

Ioannis Ziogas examines the relationship via the story of Myrrha as told in the Metamorphoses of Ovid. He argues that poetry desire and the law all depend, dictate and prescribe each other. In the context of desire and intimacy there is a tension, or even a fundamental antagonism, between its regulation through poetry and its regulation through imperial mandates and statutes.

Renata Grossi continues the discussion of the relationship between law and love by considering Zenon Bańkowski's argument that law and love are 'entangled', 'necessary', and even 'dependent' on each other, and that together they form the 'unity' that is required for us to live a lawful life. In order to engage with this argument, Grossi then asks us to consider a further question, what type of love best fits with this argument? She concludes that while Bańkowski relies on ideas of love that spring from the Classical (eros), the Christian (agape) and the romantic traditions, a conception of love that also fits his argument is friendship love (philia).

An important part in considering the relationship between law and love is to engage with how love informs legal doctrine? Perhaps one of the most obvious places of intersection between law and love is in the legal regulation and definition of the institution of marriage.

Alicia Simmonds considers informal and formal norms governing love in colonial Australia by examining 211 breach of promise cases. In her article she discovers a contradiction: almost half of the female plaintiffs had children, and yet a lack of female virtue operated as a complete defence for the predominantly male defendants. She posits that breach of promise actions operated as a supplement to maintenance for women. In this study Simmonds touches upon an important theme in the regulation of love and intimacy in marriage - its relationship with the strong(er) expectation that the institution is governed by expectations of economic support.

The tension in the marriage relationship, which must be negotiated by law, between on the one hand love and desire, and on the other economic support and more contentious matters of the state/nation is

$9 \quad$ For a discussion of this, see the articles by Grossi and Neoh in this collection. 
also a discussion that occurs in Ioannis Ziogas's article. Here we see that as far back as Augustan Rome the state sought to regulate intimacy by criminalising adultery and outlawing sex outside of marriage.

But marriage is by no means a unique location for intimacy and broken promises. Dilan Thampapillai considers 'What becomes of the brokenhearted?' in the doctrine of unconscionability that usually falls under the consideration of commercial law. In a 1990s case, Louth $v$ Diprose, the High Court of Australia established the idea that romantic love could be a disadvantage in commercial transactions, and could therefore give rise to the doctrine of unconscionability. Since then, in subsequent cases the courts appear to have treated the case 'as a troublesome precedent' and appear to be retreating from it. Thampapillai considers this doctrinal shift. The article raises the question for future research as to whether this shift indicates a change in our social and cultural perceptions of romantic love.

In the beginning of this Introduction, we discussed the idea of love for the nation as being at the core of the political making of a nation. This idea is very much at the heart of Luis Gómez Romero's article on the erotic jurisprudence of Ernesto 'Che' Guevara. Romero analyses Guevara's claim that 'the true revolutionary is guided by great feelings of love' and argues that the emotional constituents of Guevara's political and legal thought have played an essential role in the cultural configuration of his political myth. But more than this Romero argues that love is what enabled Guevara, and can enable others, to see the injustices in the world.

This point leads to an important question that underlies this project. Why love? What do we achieve in our understanding of law when we pit it against love? The answer we think lies in another more general question that is about the connection of human activity, and the connection of law, not only to what we think, but also what we feel. The diverse collection of articles in this Special Issue of Law in Context offers some insights into past discussions, and offers some lines for further inquiry along this theme. If you, the reader, find the collection valuable, the following people should take credit for it: the participants at the colloquium who together created an atmosphere of collegial discussion that led to these fruitful ideas; the Humanities Research Centre at the Australian National University for hosting the colloquium; and the editors of this journal for embracing the idea of a Special Issue on law and love, and providing such excellent editorial support. However, if you find the collection less than satisfactory, they should in no way share in the blame. 